\title{
Health-Seeking Behaviour among Migrant Female Head Porters in the City of Accra, Ghana
}

\author{
Ziblim Shamsu-Deen \\ (Corresponding Author) \\ Department of Community Health and Family Medicine, \\ University for Development Studies, Ghana \\ zshamsu72@gmail.com/sziblim@uds.edu.gh \\ Yidana Adadow \\ Department of Community Health and Family Medicine, \\ University for Development Studies, Ghana \\ DOI//http://dx.doi.org/10.4314/gjds.v16i2.7
}

\begin{abstract}
Migration is an important feature of human development and a significant driver of societal change and well-being across populations. One key aspect of contemporary migration is the rise in female migration, contributing to the debate on urbanization with implications for the health of migrants. This study examined the health behaviour of migrant female head porters in Accra. The study design was cross-sectional with an interview-administered survey. A multistage sampling technique was employed to select communities and 213 respondents. Data were analysed using the SPSS software. From the results, $41.1 \%$ were within ages $15-19$ years, $41.7 \%$ were Mamprusis, and $59.1 \%$ were not married. About $65.5 \%$ knew the existence of a health facility around their residence, with $75.5 \%$ seeking healthcare outside orthodox health facilities. A significant association was established between marital status and education and where healthcare was sought. Respondents who saved money, had Health Insurance cards, and receive support from others were more likely to visit health facilities. The study concludes that the predictors of health-seeking behaviour among the respondents are the possession of health insurance; level of saving, social support they receive from others including marital status and education. Respondents should be encouraged to possess health insurance and save money.
\end{abstract}

Keywords: Health-Seeking, Behaviour, Migrants, Female, Head-Porters, Behaviour 


\section{BACKGROUND}

Migration is an important feature of human development as well as a significant driver of societal change and well-being of different population. Migration remains a key means by which people escape undesirable societal happenings (Castles \& Miller, 1993; Foresight, 2011). One key aspects of contemporary migration is the global rise in female migration, contributing immensely to the on-going rapid urbanization worldwide, with serious implications for the health of migrants and the receiving populations (Castles \& Miller, 1993; Adepoju, 2011). Migrant workers are recognised to be among the most vulnerable members of society. They are often engaged in what are known as 3-D jobs: dirty, dangerous, and demanding (Quandt et al., 2013). Regrettably, the relationship between migration and health among these female has received little attention (IOM, 2014). The female migrants low-skilled and are concentrated in dense and in informal settlements with low levels of health care, water and other services, rendering them vulnerable to ill health (Foresight, 2011). Besides their vulnerability, migrant workers face higher rates of negative occupational exposures, leading to poor health outcomes, workplace injuries, and occupational fatalities (Quesada, Hart, \& Bourgois, 2011).

In the face of these occupational related fatalities, accessing health care services also becomes a daunting task (Adepoju, 2011). Migration and health share a complex bidirectional relationship (IOM, 2014) and the spread of certain communicable diseases (Iddrisu, 2001; IOM, 2014). Notwithstanding the major regional migratory flows over the years, improving the health of migrant workers has been challenging (Amrith, 2014). There is a general consensus among migration scholars that conditions both at origin and destination have an influence on the health of the migrants. But scholars such as Schenk (2007) further argue that conditions at the origin and destination can lead to deprivation, thereby leading to greater exposure to several vulnerabilities (Schenk, 2007). Thus an understanding of the health implications of migration is not only of contemporary relevance but also useful for the foreseeable future. This is more crucial as most of the people involved in the migration stream are the economically active of the world female population. This paper examines the nexus of migration and health seeking behaviour among migrant's female porters working and residing in Accra. There are a substantial number of studies on migrant female porters in Ghana, but very few studies that focus on the link between migration and health especially with regards to access to health care services and migrant female porter's health seeking behaviours at their destination. 


\section{Health Care Seeking Behaviour}

Understanding people's health-seeking behaviour enhances the knowledge of their health experience and aid in reducing delay in diagnosis and treatment. It improves treatment and compliance as well as assists in developing health education strategies (Shuster \& Magidi, 2015). According to Blaxter (2007), "health" as a concept has different meanings across cultures. According to Frank (2002), health is conceptualised to include physical health as well as social and mental well-being. This conceptualisation sees health as a positive state of an individual's well-being. Within this framework and in this study, health-seeking is conceptualised as a process where individuals perceive, evaluate, and take any form of action or decide not to act to a physical or mental illness whether perceived or real. The actions the individuals may take include but not limited to self-diagnosis and self-medication including care from people who may be described as therapy managing group or migrant social network who may utilise both formal and informal healthcare services available to them.

\section{Historical Perspective of Female Porters in Ghana}

The word "kayayo" is coined with two words from two different Ghanaian local languages: "kaya" in Hausa which means 'load' and "yoo" in the Ga language, which means 'carry.' "Kayayo", therefore, literally means "to carry the load." In this sense, "Kayayo" is more or less a form of occupation in which people (particularly young women and girls) carry loads of goods on their heads from one place to another for a fee. In contemporary usage, the term is also to mean a migrant young woman or a teenage girl who is engaged in informal work in urban centres (Opare, 2003).

A "kayayoo" is a lady who carries goods and wares on her head for traders and shoppers in and around the commercial business district in Ghana for a negotiable fee. "Kayayei" is typically younger and unskilled with little or no education who migrated from the underdeveloped rural areas in the north part of Ghana in search of jobs in the cities (Yeboah \& Appiah-Yeboah, 2009). Northern Ghana is noted as a place with abject poverty. The major occupation there is agriculture which is characterised by unpredictable rain fall pattern as a result of environmental degradation. Drought, unfertile soil due to excessive and bad farming practices (Ahlvin, 2012). This and other socio-cultural practices such as child/forced marriage and ethnic conflicts at the origin "kayayei" have widened the poverty gap and push them to migrate to cities in the south with the aim of bettering their situations. A study conducted by Ahlvin, (2012) reported that many parents of "kayayei" decision to migrate were encouraged by their parents (mostly mothers). As a result of their lack of formal education, they end up working in the informal sector and 
have no decent place of accommodation, thus exposing them to the harsh weather conditions and rape.

\section{STUDY AREA AND STUDY METHODOLOGY}

The locational context of this study is Accra. It is the national capital and the most populous city in Ghana. According to the Ghana Statistical Service (2012), Accra was estimated to be 2.27 million as of 2012 with a population growth rate of $2.7 \%$ per annum. Accra serves as the economic and administrative hub of the greater Accra region and Ghana as a whole. The area is noted to be the most urbanised city in the country with $87.4 \%$ of its total population living in urban centres. The map below illustrates the selected markets for the study.

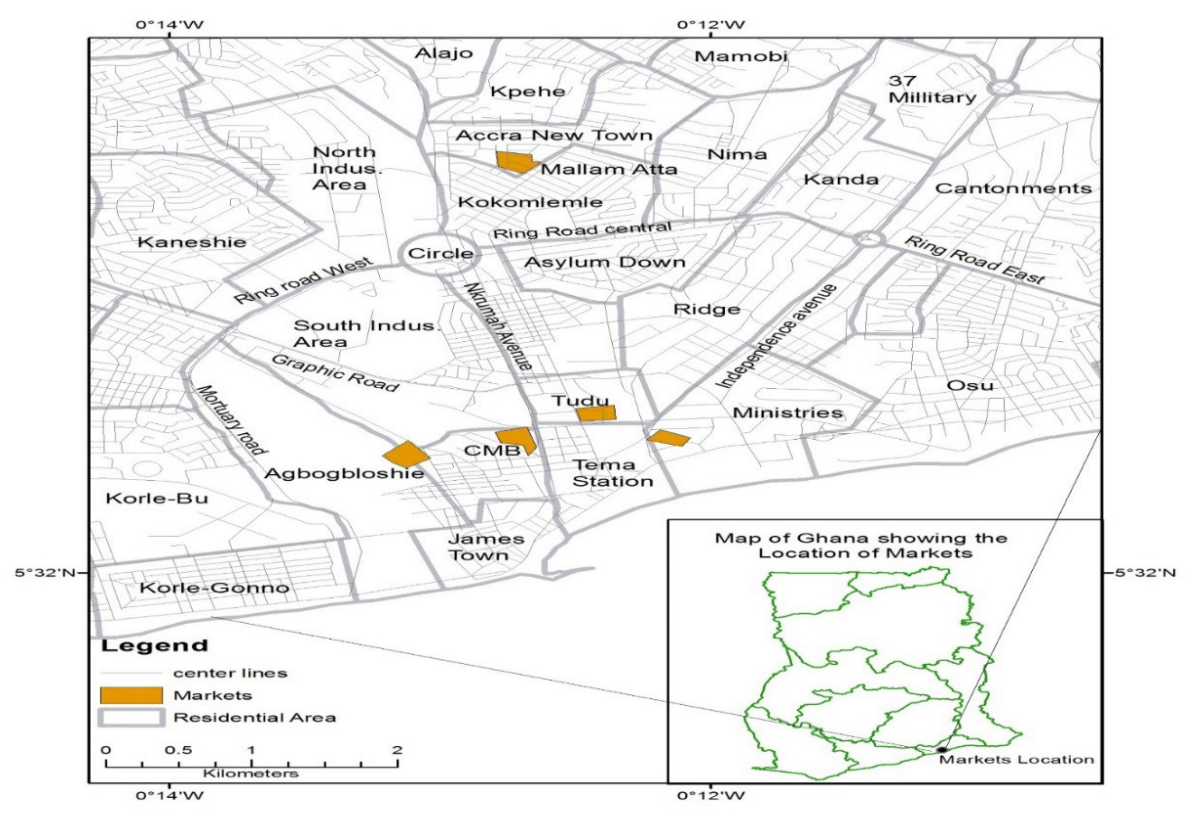

\section{Figure 1: Map of Accra showing the selected study areas}

Apart from the use of documented sources, the study also generated first-hand information from the field. The study commenced with a preliminary visit to the selected areas to have in-depth knowledge and understanding of the activities of the female porters including their health-seeking behaviour. The study basically relied on mixed method approaches taking into consideration the data needs and the sensitive nature of the study. The survey was conducted in all the selected markets using a questionnaire as its primary data collection tool. The approach 
is deemed appropriate when responses to some commonly experienced aspects of their health and working environment (Dovlo, 2005). Through such interactive discourse, respondents are able to provide insights on the perspective of the topic under investigation, revealing clues to the social contexts that shape their views (Baah-Ennumh, Amponsah \& Martina, 2012). In all, two hundred and sixteen (216) respondents were interviewed using survey questionnaires. In addition to the survey, in-depth interviews were conducted with some of the migrant porters. Again, eight focus group discussions were conducted - two each in the selected areas of the study. The FGD was conducted to cross check the information given during the individual interviews and the survey.

A multi-stage sampling technique was employed in the selection of the respondents. The first was to purposively select the markets in the city for the study according to existing literature. Based on the literature the following markets were selected: Agbogbloshei, Cocoa Marketing Board market, Tema lorry station, Mallam Attah market and Tudu market all the selected areas were within the Central Business District (CBD) of Accra which is noted for the activities of the migrant female porters. The second stage was to visit the selected markets to meet with the leadership of the porters and to ascertain the population of porters at selected areas. The number of female porters selected in the various communities at their destination was based on the total population of female porters provided by the leadership of the porters at their various locations. From the list, Tema Lorry Station had 258 porters, Mallam Atta market, 263, Agbogloshie, 162, and CMB Lorry Station, 76. It was based on these numbers that Tema Station and Mallam Atta had a high number of respondents for the study than the others as indicated in Table 1.

Table 1: Sample communities in Accra and number of respondents

\begin{tabular}{|l|l|l|}
\hline $\begin{array}{l}\text { Communities Selected at the Destination } \\
\text { (Accra) }\end{array}$ & $\begin{array}{l}\text { Total Number porters } \\
\text { (Kayayei) }\end{array}$ & $\begin{array}{l}\text { Number of } \\
\text { respondents }\end{array}$ \\
\hline Tema Lorry Station & 258 & 69 \\
\hline Mallam - Attah Market & 263 & 65 \\
\hline Agbogloshie Market & 162 & 47 \\
\hline Cocoa Marketing Board Station (CMB) & 76 & 35 \\
\hline Totals & 759 & 216 \\
\hline
\end{tabular}

Source: Field work (2016) 


\section{RESULTS AND DISCUSSIONS}

\section{Socio-demographic Characteristics}

The study selected a total of 213 respondents from the four locations. From the results, the majority (44.4\%) of the respondents were within the ages 15-19 years, $25.4 \%$ were within $20-24$ years with $21.5 \%$ being 25 years and over. In terms of ethnicity, 41.7\% were Mamprusi, 35.6\% Dagombas and 22\% being Tamplinsi. Again, the majority of the respondents were not married (59.1\%), 15.9\% were married and $5.6 \%$ divorced. On the educational attainment of respondents, as high as $54.5 \%$ of them had primary level education, $25.4 \%$ had no formal education, with only $2.8 \%$ having SHS/Vocational education. See Table 2. 
Table 2. Socio-Demographic Characteristics of respondents

\begin{tabular}{|c|c|c|c|}
\hline SN & Variables & Frequency & Percent \\
\hline \multirow[t]{6}{*}{1} & Age Group Respondents & & \\
\hline & 10-14 years & 27 & 12.7 \\
\hline & 15-19 years & 86 & 40.4 \\
\hline & 20-24 years & 54 & 25.4 \\
\hline & $25^{+}$ & 46 & 21.5 \\
\hline & Total & 213 & 100.00 \\
\hline \multirow[t]{6}{*}{2} & Ethnicity & & \\
\hline & Dagomba & 76 & 35.6 \\
\hline & Mamprusi & 89 & 41.7 \\
\hline & Tamplinsi & 47 & 22.0 \\
\hline & Others & 4 & 1.8 \\
\hline & Total & 213 & 100.00 \\
\hline \multirow[t]{6}{*}{3} & Marital Status of Respondents & & \\
\hline & Singled & 126 & 59.1 \\
\hline & Married & 34 & 15.9 \\
\hline & Co-habiting & 42 & 19.7 \\
\hline & Divorced & 11 & 5.6 \\
\hline & Total & 213 & 100 \\
\hline \multirow[t]{6}{*}{4} & Educational Level of Respondents & & \\
\hline & No Formal Education & 54 & 25.4 \\
\hline & Primary Education & 116 & 54.5 \\
\hline & JHS & 37 & 17.4 \\
\hline & SHS/Vocational & 6 & 2.8 \\
\hline & Total & 213 & 100 \\
\hline
\end{tabular}

Source: Field survey 2016

\section{Knowledge of existing health facilities}

Awareness of the health services in one's locality is a requirement for their consequent usage. From the results, approximately two thirds (65.5\%) of the respondents knew at least one hospital or a clinic and some pharmacies where they could access health care services. More than a third (35.5\%) of the respondents were not aware of any health facility around the place they reside. 


\section{Areas respondents seek health care}

Information provided in table 3 show places where respondents sought care. About one-quarter $(24.5 \%)$ sought care in a health facility and the rest $(75.5 \%)$ sought care outside health facilities. The health facilities where care was sought include clinics, polyclinics, hospitals, maternity homes and private health centres. Those who sought healthcare outside the health facilities reported using both chemists' shops and local herbs. See table 3.

Table 3: Percentage distribution of places where health care was sought

\begin{tabular}{|l|l|}
\hline & Percent \\
\hline Places/ Health Facilities & $(\mathrm{N}=216)$ \\
\hline Place Sought Health Care When Sick & \\
\hline Hospital & 8.5 \\
Clinics & 16.0 \\
Chemical shops & 51.5 \\
Herbalist & 17.8 \\
Others & 6.2 \\
\hline
\end{tabular}

Source: Field survey 2016

Some of the respondents who sought health care outside health facilities mentioned that they bought medicines from drug peddlers and chemists' shops in the market. Others used traditional medicine that they brought along from their origins in the north. Respondents who sought health care from health facilities indicated that where they reside in Accra, the hospital or the clinics were the safest places to receive health care. They indicated that at the health facility, health professionals are always available to attend to patients.

The hospital is the safest place to go when you are sick. I fell ill last month and my friends asked me to go home for treatment. My madam who I help in the market to carry her goods any time she comes to market asked me not to go. She took me to the hospital and after taking the medication, I was better to continue with my work. I thought I was going to die but the doctors were good and caring. I advised all my fellow Kayayei to visit the hospital when they are sick (Memuna, 20 years, "Kayayo").

As regards seeking healthcare outside health facilities, long distance and time spent in receiving medication were some of the barriers. They opined that where they reside makes the facilities geographically inaccessible. However, a sizeable number indicated that they lived close to a health facility, implying that distance to, and time spent at the health facility is a major determinant in their health- 
seeking behaviour. This corroborates claim by Iddrisu, (2001) and Awumbila (2007) that distance and time spent at a health facility contribute to low attendance to health facility among the rural folks in developing countries. The long waiting hours at health facilities serve as a hindrance for accessing health care services. Respondents who indicated that they accessed health care services at the health facilities reported long hours of waiting before attending to as a challenge to their use of the services.

The first time I went to the hospital when I was sick, I spent almost the whole day at the facility before seeing the doctor. What worried me was that I spent money to travel to and from the facility and spent the whole day. It is not the money I spent but the time I wasted at the health facility. Since then any time I am sick with the same symptoms, I just walk to the chemist shop and buy the same medication that was given to me at the hospital. I prefer that to wasting the whole day without working. (Serina, 23 year old "Kayayo").

This claim ties in well with Onokerhoraye, (1999) and Yeboah, (2008) assertion that long delays at health facilities are a common phenomenon at most hospitals in Ghana. These experiences make the patients lose confidence in orthodox health care and therefore resort to other means of healthcare. Apart from the distance and the waiting time at the health facilities, respondents also stated that they could not afford various services at the facilities because of economic reasons. Some respondents preferred traditional healers to orthodox health care. This finding resonates with the argument that belief in the effectiveness of a health service predicts the likelihood of using that service than those that are not noted to be effective (Rosenstock et al., 1994). Some respondents believed in traditional medicine and could rely on it anytime they were sick. According to them, in most of the rural communities at their origin there are no health facilities, therefore, going to orthodox facilities is a new thing to them.

In my community in the north, there is no health facility and most of the people resort to herbs when sick. We use the herbs to treat ourselves in the village. So here when I feel that I am not feeling well I use the local herbs I brought from the village. I don't want to be used to hospital attendance because there is none in my village in the north. In my village is only the rich who offer to attend hospital when sick. (Mamata, an 18 year old "Kayayo")

As noted by Twumasi (2005) and Wolffers, Verghis and Marin (2003), people can maintain a parallel set of orientations and may be positively oriented both to 
traditional and modern scientific medical practices. This illustrates the contribution of traditional medicine in dealing with ill health in Ghanaian society, especially in rural areas.

\section{Socio-demographic Characteristics and where health care is sought}

From the results, marital status and level of education were significantly associated with the places where health care was sought. However, places, where health care was sought, does not vary by age group and a number of living children (Van Landingham, 2005; WHO, 2010). Specifically, the largest proportion of respondents who sought health care in a health facility (50.0\%) were cohabiting, followed by those who were widowed (40.0\%). Again, about $24.4 \%$ of those who had never been married sought care from health facilities. The least proportion (17.2\%) of respondents who sought care from a health facility were married. Those who had children were noted to have experience in childbearing and did not see the need to visit the hospital especially when they are pregnant. Further, the proportion of those who used health facilities increased with the level of education. None of those with no education used health facilities; and about one-fifth (19.9\%) of those with primary education and one-fourth (25.0\%) of those with Junior High School, education used health facilities. In addition, while about $29 \%$ of those with vocational/technical/secondary education sought care from health facilities. Even though age did not show a significant association with a place where healthcare was sought, there is a kind of pattern observed. The proportion that used health facilities was highest among respondents in the older age groups. For instance, the use of health care facilities such as the hospital and clinics kept increasing with increasing age. Respondents 10-14 years, 15-19 years, 20-24 years and 25 years and above were $17.2 \%, 24.7 \%, 21.8 \%$ and $32.6 \%$ respectively. With regards to the number of living children, the highest proportion of respondents who used health facilities are respondents who have one child (28.6\%), followed by those with four children (27.3\%). None of those with five and six children used health facilities. See table 4. 
Table 4: Socio-demographic characteristics and where healthcare is sought

\begin{tabular}{|c|c|c|c|c|}
\hline \multirow[b]{2}{*}{ Characteristics } & \multicolumn{2}{|c|}{ A place sought care when sick } & \multirow[b]{2}{*}{$\mathrm{N}$} & \multirow[b]{2}{*}{$X^{2}$} \\
\hline & In a health facility & Not in a health facility & & \\
\hline Age Group & $(\mathrm{N}=53)$ & $(\mathrm{N}=163)$ & & 5.451 \\
\hline $10-14$ & 17.2 & 82.8 & 29.0 & \\
\hline $15-19$ & 24.7 & $75 \cdot 3$ & 89.0 & \\
\hline $20-24$ & 21.8 & 78.2 & 55.0 & \\
\hline 25 and above & 32.6 & 67.4 & 43.0 & \\
\hline Marital status & & & & $9.011^{* *}$ \\
\hline Never married & 24.4 & 75.6 & 135.0 & \\
\hline Married & 17.2 & 82.8 & 58.0 & \\
\hline Co-habitation & 50.0 & 50.0 & 8.0 & \\
\hline Divorced/widow & 40.0 & 60.0 & $15 \cdot 0$ & \\
\hline $\begin{array}{l}\text { Number of living } \\
\text { children }\end{array}$ & & & & 1.896 \\
\hline Have no living children & 24.7 & $75 \cdot 3$ & 146.0 & \\
\hline 1 & 28.6 & 71.4 & 28.0 & \\
\hline 2 & 25.0 & 75.0 & 20.0 & \\
\hline 3 & 12.5 & 87.5 & 8.0 & \\
\hline 4 & $27 \cdot 3$ & 72.7 & 11.0 & \\
\hline 5 & 0.0 & 100.0 & 1.0 & \\
\hline 6 & 0.0 & 100.0 & 2.0 & \\
\hline Level of education & & & & $7.845^{*}$ \\
\hline No education & 0.0 & 100.0 & 2.0 & \\
\hline Primary & 19.6 & 80.4 & 102.0 & \\
\hline Middle/JHS & 25.0 & 75.0 & 68.0 & \\
\hline $\begin{array}{l}\text { Vocational/Technical/ } \\
\text { Secondary }\end{array}$ & 28.6 & 71.4 & 28.0 & \\
\hline
\end{tabular}

Source: Field Survey, 2016

${ }^{* *} \mathrm{P}<0.01,{ }^{*} \mathrm{P}<0.05$

\section{Economic factors and Health-Seeking behaviour}

The study revealed that only respondents with National Health Insurance Scheme (NHIS) status were statistically significant with the place where health care was sought. However, savings and support from institutions/individuals were not significantly associated with a place where health care was sought. Specifically, 
about $32 \%$ of the respondents who had NHIS cards sought care in a health facility, compared to $18.8 \%$ of those without NHIS cards. Again, table 4 shows that the use of healthcare was higher among those who had to save enough money, although this is not statistically significant. About $22.7 \%$ of respondents who saved less than GHS10o sought care in a health facility, about $24 \%$ of respondents who saved GHS10o-GHS20o and 41.4\% of those who saved GHS201 and above did so. Again, $29.4 \%$ of those who received support from institutions/individuals and about $25 \%$ of those who did not receive such support sought care in a health facility (See Table 5).

Table 5: Economic factors and health seeking behaviour

\begin{tabular}{|l|l|l|l|l|}
\hline & \multicolumn{4}{|l|}{ Place sought care when sick } \\
\hline Characteristics & $\begin{array}{l}\text { In a health } \\
\text { facility }\end{array}$ & $\begin{array}{l}\text { Not in a health } \\
\text { facility }\end{array}$ & N & $X^{2}$ \\
\hline Savings & & & & 4.276 \\
\hline Less than GH 100 & 22.7 & 77.3 & 75 & \\
\hline GH 100-GH200 & 23.5 & 76.5 & 81 & \\
\hline GH201 and above & 41.4 & 58.6 & 29 & \\
\hline $\begin{array}{l}\text { Receive assistance from } \\
\text { institutions/individuals }\end{array}$ & & & & 0.31 \\
\hline Yes & 29.4 & 70.6 & 34 & \\
\hline No & 24.9 & 75.1 & 173 & \\
\hline Do you have NHIS card & & & & $4.825^{*}$ \\
\hline Yes & 31.9 & 68.1 & 94 & \\
\hline No & 18.8 & 81.2 & 117 & \\
\hline
\end{tabular}

Source: Field survey, 2016.

${ }^{* *} \mathrm{P}<0.01,{ }^{*} \mathrm{P}<0.05$

The respondents saw the importance of keeping and active NHIS card and how it could help one to receive healthcare.

I always go to the hospital when I am sick because of the health insurance card. It was given and paid for us by the Ministry of Gender and Social Protection. With this opportunity even if I will walk $4 \mathrm{~km}$ to access modern health care I will do that. (Amatu, a 21 year old "Kayayo").

They further intimated that they fall sick often because of the work they do on a daily basis. They believe that to stay on the job, one has to remain healthy.

My brother! The nature of our work is that you have to be very strong and healthy before you can carry the load. My strength and health is 
my wealth. For this reason, I don't jock my health. I contribute GHC 10 weekly towards my health. (Salima, 23 year old "Kayayo").

This finding contradicts Bemah (2010) claim that Kayayei does not make any provision towards their health care needs and that they are more particular about their cooking utensils and capital to start businesses when they return to their origin in the north.

\section{Predictors of Health-Seeking Behaviour among respondents}

Whether or not a respondent will access health care in a health facility or not depends on a number of factors. Table 6 presents the logistic regression model of the effects of respondents' socio-demographic and environmental factors on their health-seeking behaviour. The model R-squared indicates that about $21 \%$ variations in the health-seeking behaviour of respondents in the study are explained by the socio-demographic and the environmental characteristics. In all, age, level of education and mode of the waste collection are significant predictors of health seeking behaviour among respondents. The age and level of education of respondents have a positive effect on their health-seeking behaviour while the mode of the waste collection had a negative effect. 
Table 6: Logistic regression model on determinants of health-seeking behavior $(\mathrm{N}=216)$

\begin{tabular}{|c|c|c|c|c|}
\hline \multicolumn{5}{|l|}{ Model 1} \\
\hline Variable & Coef. & Robust Std. Err. & Odds ratio & \\
\hline \multicolumn{5}{|l|}{ Age Group ( $R C$ is $10-14)$} \\
\hline $15-19$ & 1.470 & 0.983 & $4 \cdot 349$ & \\
\hline $20-24$ & 2.146 & 1.120 & 8.555 & $* *$ \\
\hline \multicolumn{5}{|c|}{ Marital status ( $\mathrm{RC}$ is Never married) } \\
\hline Married & 1.114 & 0.897 & 3.047 & \\
\hline Divorced/widowed & 2.414 & 1.651 & 11.184 & \\
\hline Number of living children & -0.323 & 0.437 & 0.724 & \\
\hline \multicolumn{5}{|l|}{ Level of education (Primary) } \\
\hline Middle/JHS & 1.657 & 0.974 & 5.242 & $*$ \\
\hline Vocational/Technical/Secondary & 2.267 & 1.156 & 9.646 & $* *$ \\
\hline \multicolumn{5}{|l|}{ Water ( $R C$ is Within residence) } \\
\hline Outside residence & 0.937 & 1.451 & 2.552 & \\
\hline \multicolumn{5}{|l|}{ Toilet ( $\mathrm{RC}$ is within the residence) } \\
\hline Outside residence & -1.381 & 1.405 & 0.251 & \\
\hline \multicolumn{5}{|l|}{$\begin{array}{l}\text { Waste collection ( } \mathrm{RC} \text { is within the } \\
\text { residence) }\end{array}$} \\
\hline Outside residence & -2.026 & 0.992 & 0.132 & $* *$ \\
\hline Constant & -2.280 & 1.741 & 0.102 & \\
\hline Model R² & & 0.208 & & \\
\hline
\end{tabular}

${ }^{* *} \mathrm{P}<0.05,{ }^{*} \mathrm{P}<0.10$

Source: Field survey, 2016

Table 6 shows that respondents aged 20-24 years are 8.555 times more likely to seek healthcare in a health facility than those aged 10-14 years. This may be because respondents aged 20-24 years are involved in activities that earn them more income as compared to those who are younger. It is expected that with higher income when they are sick they will visit health facilities for treatment. Again, respondents with Middle/Junior High School education are 5.242 times likely to seek care in a health facility than their counterparts with primary education. In addition, respondents with Vocational/Technical/Secondary education are 9.646 times likely to seek health care in a health facility than those with primary education. Education gives an individual a wider opportunity in life and also accepts more objective and scientific explanation about the disease. Respondents with higher education are more likely to get better offers due to their ability to speak English, their higher 
level of confidence and bargaining power, so that they earn more, save more, and are therefore able to go to a health facility to seek care. Those with lower education may not be in the position to afford the fees in health facilities and may also lack knowledge about the benefit of going to a health facility to seek care. Again, educated respondents found it relatively easier to navigate hospital procedures and therefore feel comfortable at health facilities compared to non-educated ones who could hardly speak English, read or write. This finding corroborates those of Wilson et al. (2005) and Oladipo (1992), who suggest that education is positively related to the health of rural-urban migrants as it enables them to break the language barrier with healthcare officials.

In terms of the mode of disposing of waste by respondents in their homes, those whose waste was collected outside their homes were less likely to seek health care in a health facility as compared to those whose waste was collected in their residences. Waste collection within residences in the neighbourhoods where the respondents reside is not usually frequent. This brings about disease transmission in homes because waste is left within the residences for weeks before it is collected by waste management companies. Probably due to frequent illnesses associated with the uncollected waste within the homes, this category of people may be faced by financial constraints to accessing health care. Thus they may rather easily resort to seeking health care in other avenues than health facilities.

In Model 2, Table 7, other variables that affect health-seeking behaviour were controlled to see if the variables that were significant in model 2 were still robust. The R-square in Model 2 is 0.342 . This implies that $34 \%$ of the variations in healthseeking behaviour of female migrant porters are explained by socio-demographic characteristics, environmental factors and other control variables. The Model also shows that age, marital status and mode of waste collection in homes were significant predictors of health-seeking behaviour of female porters. Age and marital status have a positive effect on health-seeking behaviour while the mode of waste collection has a negative effect. Older female porters are more likely to seek health care in a health facility compared to those in the younger age group of 15-19 years. Also, female porters who were widowed were more likely to seek health care from a health facility than their counterparts who have never married. With regards to the mode of waste collection, female porters who had their waste collected outside the house were less likely to seek health care in a health facility compared with those who had their waste collected within their residence.

Table 7: Logistic Regression Model on Determinants of Health Seeking Behaviour

Model 2 


\begin{tabular}{|c|c|c|c|c|}
\hline Variables & Coef. & Robust Std. Err. & Odds ratio & \\
\hline \multicolumn{5}{|l|}{ Age Group ( $R C$ is 10-14) } \\
\hline $15-19$ & 1.688 & 0.994 & 5.407 & * \\
\hline $20-24$ & 1.634 & 1.911 & 5.125 & \\
\hline \multicolumn{5}{|c|}{ Marital status ( $\mathrm{RC}$ is Never married) } \\
\hline Married & 0.163 & 1.319 & 1.177 & \\
\hline Divorced/widowed & 3.755 & 1.928 & 42.739 & $* *$ \\
\hline Number of living children & -0.629 & 0.540 & 0.533 & \\
\hline \multicolumn{5}{|l|}{ Level of education (Primary) } \\
\hline Middle/JHS & 2.613 & 1.905 & 13.635 & \\
\hline Vocational/Technical/Secondary & 2.694 & 1.943 & 14.785 & \\
\hline \multicolumn{5}{|l|}{ Water ( $\mathrm{RC}$ is Within residence) } \\
\hline Outside residence & 0.171 & 1.761 & 1.186 & \\
\hline \multicolumn{5}{|l|}{ Toilet ( $\mathrm{RC}$ is within the residence) } \\
\hline Outside residence & 0.088 & 2.093 & 1.092 & \\
\hline \multicolumn{5}{|l|}{$\begin{array}{l}\text { Waste collection ( } \mathrm{RC} \text { is within the } \\
\text { residence) }\end{array}$} \\
\hline Outside residence & -2.733 & 1.530 & 0.065 & * \\
\hline \multicolumn{5}{|l|}{ Savings ( $R C$ is less than $G H$ 100) } \\
\hline GH $100-G H 200$ & 1.317 & 1.575 & $3 \cdot 733$ & \\
\hline GH2O1 and above & 0.700 & 1.443 & 2.013 & \\
\hline \multicolumn{5}{|c|}{$\begin{array}{l}\text { Receive Assistance from the institution } \\
\text { (RC is Yes) }\end{array}$} \\
\hline No & $-4 \cdot 385$ & 2.712 & 0.012 & \\
\hline \multicolumn{5}{|l|}{ Have NHIS card ( $R C$ is yes) } \\
\hline No & -0.822 & 1.706 & 0.440 & \\
\hline Constant & 1.685 & 3.147 & $5 \cdot 391$ & \\
\hline Model R2 & & 0.342 & & \\
\hline
\end{tabular}

${ }^{* *} \mathrm{P}<0.05,{ }^{*} \mathrm{P}<0.10$

Source: Field survey, 2016

\section{CONCLUSION}

Most of the female porters sought health care in avenues other than health facilities. These avenues included drug peddlers, local herbalists and Chemists' shops. Those who used traditional medicines mostly brought them along from their points of origin. Three factors influence female porters to access health care. 
These are their own savings, support from institutions and NHIS status. Of these, the most important is own savings. It is obvious that without financial muscle sick people cannot pay for health services by themselves. Again, the proximity of the health facilities and availability of health staff facilitate the health seeking behaviour of porters when sick. Of the range of factors discussed in the chapter, age and marital status were generally found to have a positive effect on health-seeking behaviour. Older porters were more likely to seek health care in a health facility compared to those in the younger age group of 15-19 years, and married females were also more likely to seek health care in a health facility compared to unmarried ones. Again, the study found that female porters who have their waste collected outside the house were less likely to seek health care in a health facility compared with those who have their waste collected within their residence. A relationship, thus, exists between sanitation and health-seeking behaviour of migrant female porters at their destination. The analysis showed that older female porters were more likely to seek health care in a health facility than younger ones. It is suspected that this has been so because of the kind of activities that porters in various age groups are engaged in and the amount of money they are able to make in a day. The patronage of health services outside health facilities by younger female porters has implications for their general health in the future since they could be introduced to wrong medication without any diagnosis.

\section{References}

Adepoju, A. (2011) Reflections on International Migration and Development in SubSaharan Africa African Population Studies, 25(2) pp 298-319

Ahlvin, K. (2012). “The Burden of the Kayayei: Cultural and Socio-economic Difficulties Facing Female Porters in Agbogbloshie," PURE Insights: 1(4) https:// digitalcommons.wou.edu/pure/vol1/iss1/4

Amrith, S.S. (2014). Migration and health in Southeast Asian history. Lancet; 384, pp. 1569-70.

Awumbila, M. (2007). Internal Migration, Vulnerability and Female Porters in Accra, Ghana. Available at: RL:http://www.paa2007.princeton.edu/download. aspx?submissionId $=70865$

Baah-Ennumh1, T.Y., Amponsah, O, and Martina, O.A. (2012). The Living Conditions of Female Head Porters in the Kumasi Metropolis, Ghana. Journal of Social and Development Sciences, 3(7), pp. 229-244,

Blaxter, M. (2007). Evidence for the Effect on Inequalities in Health of Interventions Designed to Change Behaviour, University of Bristol 
Castles, S., and Miller, M. J. (1993). The age of migration: International population movements in the modern world. Basingstoke: Macmillan.

Deri, C. (2005). Social networks and health service utilization. Journal of Health Economics, 24, pp. 1076-1107.

Dovlo, D. (2005). Taking More Than a Fair Share? The Migration of Health Professionals from Poor to Rich Countries. PLoS Med 2(5), pp. 0376 - 0379.

Foresight, U. K. (2011). Foresight: Migration and Global Environmental Change: Final Project Report. The Government Office for Science, London.

Frank P.G (2002). The Preamble of the Constitution of World Health Organization, Bulletin of the World Health Organization, 8o(2), pp $981-984$.

GSS (2012). Population Census Report. Accra. Ghana Statistical Service.

Iddrisu, A. (2001). The north south migration of young women effects and consequence. M Phil Thesis submitted to the America University of Cairo.

IOM (2005). World Migration Report: Analyses of the effects of globalization, trade liberalization and migration. IOM, Geneva.

IOM, (2014). Migration Initiatives 2014: Health of Migrants. IOM, Geneva.

Oladipo, J.A. (1992) Determinants of health care utilization in the management of Health Care Services: case study of Kwara State, Nigeria, 1992; unpublished PhD Dissertation.

Opare, J.M. (2003). Women Porters of southern Ghana. Journal of Social Development in Africa; 18(2), pp. 33-48

Onokerhoraye, A.G. (1999). Access and Utilization of Modern Health Care Facilities in the Petroleum-producing Region of Nigeria: The Case of Bayelsa State; Research Paper No. 162 Takemi Program in International Health Harvard School of Public Health, pp. 1-27

Quandt, S.A., Arcury-Quandt, A.E., Lawlor, E.J., Carrillo, L., Mar. In A.J., et al. (2013). 3-D jobs and health disparities: the health implications of Latino chicken catchers' working conditions. Am. J. Ind. Med. 56(2), pp. 206-15.

Quesada, J., Hart, L.K., and Bourgois, P. (2011). Structural vulnerability and health: Latino migrant laborers in the United States. Med. Anthropol. 30(4), pp.339-62.

Rosenstock, I.M., Strecher, V.J., and Becker, M.H. (1994). The Health Belief Model and HIV Risk Behavior Change. In R. J. DiClemente and J.L. Peterson (Eds.), Preventing AIDS: Theories and methods of behavioral interventions. New York, NY: Plenum Press, pp. 5-24. 
Schenk, L. (2007). Migration and Health: Developing an explanatory and analytical model for epidemiological studies. Int J. of Public Health, 52(2), pp. 87-96.

Schuster, L. \& Magidi, N. (2015). Deportation stigma and re-migration; Journal of Ethnic and Migration studies, 41(4), pp. 635-652.

Twumasi, P.A. (2005). Medical Systems in Ghana: A study in Medical Sociology, Second Edition. Tema: Ghana Publishing Corporation, pp. 1- 171.

Van Landingham, M. (2003). Impacts of Rural to Urban Migrant on the Health of Young Adult Migrants in Ho Chi Minh City, Vietnam. Johannesburg, South Africa: Jun $4-7$.

Wilson, D., Truman, C., Huang, J, Sheps, S., Thomas, R., and Noseworthy, T. (2005). The possibilities and realities of home care. Can J Public Health, 96(5), pp. 385-389.

Wolffers I, Verghis S, Marin, M. (2003). Migration, human rights, and health. Lancet 2003, 362(9400), pp. 2019-20.

World Health Organisation (2010). Health of Migrants - The way forward. Madrid, Spain: WHO Press; World Health Organisation; Geneva, Switzerland.

Yeboah, M. A. (2008). Gender and Livelihoods: Mapping the Economic Strategies of Porters in Accra, Ghana. Unpublished PhD Thesis. Department of Geology and Geography, Morgantown, West Virginia.

Yeboah, M.A. and Appiah-Yeboah, K. (2009). An Examination of the Cultural and Socio-Economic Profiles of Porters in Accra, Ghana. Nordic Journal of African Studies 18(1), pp. 1-21. 